\title{
Analisis Pengaruh Kualitas Pelayanan terhadap Kepuasan Pasien Rawat Inap pada RS. Bahagia Makassar
}

\author{
Roy Rocky Suprapto Baan \\ Universitas Teknologi Sulawesi Selatan \\ suprapto.roy.r@gmail.com
}

\begin{abstract}
Abstrak
Tujuan dari peneliti adalah untuk menganalisis pengaruh kualitas pelayanan terhadap kepuasan pasien rawat inap pada RS Bahagia. Dimensi kualitas pelayanan yaitu: Tangible, reliability, responsiveness, assurance dan emphaty dalam meningkatkan kepuasan pasien. Penelitian ini menggunakan metode analisis menunjukkan yaitu metode analisis dengan analisis statistik deskriptif. Hasil penelitian ini menunjukkan bahwa 1) Dimensi kualitas pelayanan (tangible, responsiveness, assurance dan emphaty) berpengaruh terhadap peningkatan pasien pada RS. RS. Bahagia Makassar. Hal ini dapat dilihat dari hasil analisis koefisien regresi dan kolerasi, 2) Berdasarkan hasil analisis mengenai faktor-faktor yang lebih dominan dalam mempengaruhi kepuasan pasien maka dimensi kualitas pelayanan assurance yang dominan berpengaruh terhadap peningkatan kepuasan pasien karena memberikan jaminan yang memuaskan dari bidan RS. Bahagia Makassar.
\end{abstract}

Kata kunci:Pelayanan, KepuasanPasien, Tangible, Reliability, Responsiveness, Assurance, Emphaty

\section{Abstract}

The aim of the researchers was to analyze the effect of service quality on inpatient satisfaction at Bahagia Hospital. The dimensions of service quality are: Tangible, reliability, responsiveness, assurance and empathy in increasing patient satisfaction. This study uses the analytical method shows the method of analysis with descriptive statistical analysis. The results of this study indicate that 1) The dimensions of service quality (tangible, responsiveness, assurance and empathy) affect the increase in patients at the hospital. Hospital Bahagia Makassar. This can be seen from the results of the analysis of the regression and correlation coefficients, 2) Based on the results of the analysis of factors that are more dominant in influencing patient satisfaction, the dominant dimension of assurance service quality affects the increase in patient satisfaction because it provides a satisfying guarantee from the hospital midwife. Bahagia Makassar.

Keywords:Services, Patient Satisfaction, Tangible, Reliability, Responsiveness, Assurance, Emphaty

\section{PENDAHULUAN}

Rumah sakit sebagai tingkat pelayanan lanjutan setelah puskesmas tentunya harus mempunyai pelayanan yang lebih baik. Rumah sakit adalah institusi pelayanan kesehatan yang menyelenggarakan pelayanan kesehatan perorangan secara paripurna yang menyediakan pelayanan rawat inap, rawat jalan dan rawat darurat(Listiyono, 2015).

Rumah sakit merupakan sarana untuk menghasilkan derajat kesehatan bagi warga masyarakat. Kegiatan di rumah sakit menyelenggarakan pelayanan melalui tindakan kesehatan secara merata dengan mengutamakan penyembuhan berbagai jenis penyakit dan pemulihan kesehatan yang diderita pasien dan dilaksanakan secara serasi dan terpadu. Setiap rumah sakit melakukan strategi pelayanan keperawatan profesional yang berorientasi pada kepuasan pasien agar rumah sakit tetap berkembang. Kepuasan pasien akan terpenuhi apabila proses penyampaian jasa pelayanan kesehatan dari rumah sakit kepada konsumen sesuai dengan apa yang dipersepsikan pasien.(Marthalena \& Nuryanto, 2017)

Kepuasan pelanggan atau pasien adalah perasaan senang atau kecewa seseorang yang muncul setelah membanding 


\section{EKOMBIS Sains}

hasil kinerja (hasil) terhadap produk yang dipikirkan terhadap kinerja hasil yang diharapkan. Kualitas pelayanan tidak bisa lepas dari kepuasan pelanggan. Pasien yang mendapatkan pelayanan yang berkualitas optimal dari rumah sakit secara otomatis akan menciptakan kepuasan pada pelanggannya.(Arie Sulistyawati \& Seminari, 2015)

Kualitas pelayanan merupakan titik sentral bagi perusahaan jasa karena akan mempengaruhi kepuasan pelanggan, pelanggan akan merasa puas apabila mereka mendapatkan pelayanan dengan kualitas terbaik. Perusahaan dapat memenangkan persaingan ketika meraka mampu menciptakan nilai dan memberi kepuasan kepada pelanggan dengan memberikan produk dan layanan yang berkualitas. (Masitoh et al., 2019)

Kualitas atau mutu pelayanan kesehatan tidak dapat lepas dari kepuasan pelanggan atau pasien. Pelayanan kesehatan yang bermutu dapat meningkatkan kepuasan pasien terhadap pelayanan yang diberikan. Selain itu, kepuasan pasien dapat dijadikan tolok ukur keberhasilan mutu pelayanan sebuah fasilitas kesehatan. Kepuasan pasien akan tercipta ketika apa yang didapat lebih besar dari yang diharapkan.(Ulumiyah, 2018)

Rumah sakit Bahagia Makasar merupakan salah satu instansi yang menyediakan layanan jasa yang berhubungan langsung dengan masyarakat yang berkaitan dengan pelayanan kesehatan adalah Rumah Sakit Bahagia Makassar dengan kapasitas tempat tidur sebanyak 36 buah hingga tahun 2018. Masalah pokok yang ditemukan adalah karena dari latar belakang yang dimiliki, dapat saja memiliki tingkat kepuasan yang berbeda untuk satu pelayanan kesehatan yang sama. Kualitas pelayanan kesehatan yang diselenggarakan oleh banyak institusi kesehatan pemerintah hampir selalu dapat memuaskan pasien, sering disebut pelayanan kesehatan yang bermutu.

Menurut Hidayatul untuk mencapai satu tingkat kesehatan yang bagus ada beberapa yang pelu diperhatikan untuk mewujudkan kecamatan yang sehat harus menyediakan pelayanan yang aman dan bermutu (Ulumiyah, 2018). Salah satu diantaranya yang dianggap mempunyai peranan yang cukup penting adalah penyelenggaraan pelayanan kesehatan. Prasyarat untuk mencapai pelayanan kesehatan dapat tercapai paripurna harus memiliki syarat diantaranya : tersedia dan berkesinambungan, dapat diterima dan wajar, mudah dicapai, mudah dijangkau dan bermutu(Radito, 2014).

Berdasarkan penelitian sebelumnya oleh Agustinawati menunjukan bahwa kualitas pelayan konsumen berpengaruh secara signifikan terhadap kepuasan konsumen pada bisnis kuliner(Agustinawati, 2016). sejalan dengan penelitian tentang pengaruh kualitas pelayanan terhadap kepuasan pelanggan restoran restoran ubud ginjar yang menunjukan bahwa variabel bukti fisik, keandalan, daya tanggap, jaminan, empati, dan perbedaan gender berpengaruh terhadap kepuasan pelanggan pada Restoran Indus Ubud.(Arie Sulistyawati \& Seminari, 2015). Penelitian lain juga menunjukan tentang analisis pengaruh kualitas pelayanan terhadap kepuasaan konsumen pada matahari dapartment store mendapatkan bahwa hasil koefesien regresi yang didapat menunjukkan variabel assurance $(\mathrm{X} 3=0,346)$ menjadi faktor terbesar yang mempengaruhi kepuasan konsumen, kemudian reliability $(\mathrm{X} 1=0,234)$, tangible $(\mathrm{X} 5=0,202)$, Responsiveness $(\mathrm{X} 2=0,192)$, sementara emphaty $(\mathrm{X} 4=0,394)$ menjadi faktor terendah yang mempengaruhi kepuasan konsumen. (Karla \& Ekonomi, 2015). Berdasarkan penelitian oleh Sri Kriswandari tentang Pengaruh Kualitas Layanan Terhadap Kepuasan Pelanggan Pt Astra 


\section{EKOMBIS Sains}

Internasional Daihatsu Ahmad Yani Bandar Lampung bahwa hasil analisis secara simultan dari kelima dimensi kualitas layanan Reabilitas, Daya tanggap, Empati, Jaminan dan Bukti fisik, kesemuanya berpengaruh sebesar $58,9 \%$ yang berarti $41,1 \%$ sisanya dipengaruhi oleh variabel yang tidak diteliti.(Kriswandari, n.d.)

Dari beberapa penelitian di atas diketahui bahwa kualitas pelayanan berpengaruh pada kepuasan konsumen. Jika kualitas pelayanan baik maka konsumen akan puas. Peneliti menggunakan metode kualitatif deskriptif dimana peneliti meneliti tentang pengaruh kualitas pelayanan pada pasien rawat inap.

Penyelenggaraan pelayanan kesehatan pada dasarnya adalah untuk memenuhi kebutuhan dan tuntutan para pemakai jasa pelayanan kesehatan (health needs and demands), yang apabila berhasil dipenuhi maka akan dapat menimbulkan rasa puas (client satisfaction) terhadap pelayanan yang dimaksud dengan mutu pelayanan kesehatan adalah menunjuk pada tingkat kesempurnaan pelayanan kesehatan dalam menimbulkan rasa puas pada diri setiap pasien. Makin sempurna kepuasan tersebut, makin baik pula mutu pelayanan kesehatan.

Berdasarkan uraian tersebut, peneliti tertarik untuk Menganalisis Pengaruh Kualitas Pelayanan Terhadap Kepuasaan Pasien Rawat Inap RS. Bahagia Makasar.

\section{TINJAUAN PUSTAKA}

\section{Pengertian Rumah Sakit}

Menurut Kementerian Kesehatan 2011 yang dikutip Manurung bahwa rumah sakit merupakan suatu institusi pelayanan kesehatan perorangan secara parnipurna atau menyeluruh yang menyediakan pelayanan rawat inap, rawat jalan, dan gawat darurat.(Wanrajib Azhari Manurung, 2015)

Menurut kamus besar bahasa Indonesia yang dikutip oleh Angga yang dimaksud dengan rumah sakit adalah rumah tempat merawat orang sakit, menyediakan dan memberikan pelayanan kesehatan yang meliputi berbagai masalah kesehatan. (Permana, 2016).Rumah sakit adalah sarana kesehatan yang menyelenggarakan pelayanan kesehatan secara merata dengan mengutamakan upaya penyembuhan penyakit dan pemulihan kesehatan yang dilaksanakan secara serasi dan terpadu dengan upaya peningkatan kesehatan dan pencegahan penyakit dalam suatu tatanan rujukan serta dapat dimanfaatkan untuk pendidikan tenaga penelitian.(Permana, 2016)

\section{Kualitas Pelayanan}

Kualitas dapat diartikan sebagai derajat yang dicapai oleh karakteristik yang berkaitan dalam memenuhi persyaratan. Ada lima dimensi kualitas pelayanan jasa menurut Tjiptono \& Chandra yang dikutip Alfi dkk yaitu Tangibles, Reliability, Responsiveness, Assurance dan Empathy, dimensi tersebut sangat berpengaruh terhadap kepuasan pelanggan. Kelima dimensi ini yang akan digunakan untuk mengukur tingkat kualitas layanan di suatu perusahaan.(Lubis \& Andayani, 2017)

Untuk mengklasifikasikan dimensi mutu perlu membagi dalam dua hal penting. pertama Mutu Produk mencakup hal nyata yang diperoleh pelanggan dan kedua Mutu Pelayanan mencakup karakteristik yang dapat diteliti atau dialami oleh pelanggan selama transaksi.

Berbagai pengertian kualitas pelayanan dapat disimpulkan bahwa kualitas pelayanan dapat diketahui dengan melihat gambar dibawah ini dimana pasien memberikan penilaian terhadap kualitas pelayanan.

Indikator yang dipakai untuk menilai suatu rumah sakit antara lain :

a. Kehandalan (Reability) Kehandalan yaitu kemampuan memberikan pelayanan yang 


\section{EKOMBIS Sains}

dijanjikan dengan segera akurat dan memuaskan, jujur, aman, tepat waktu, ketersediaan keseluruhan ini berhubungan dengan kepercayaan terhadap pelayanan dalam kaitannya dengan waktu

b. Ketanggapan

(Responsiveness) Ketanggapan yaitu keinginan para pegawai atau karyawan membantu konsumen dan memberikan pelayanan itu dengan itu dengan tanggap terhadap kebutuhan konsumen cepat memperatikan dan mengatasi kebutuhankebutuhan.

c. Jaminan (Assurance) Jaminan mencakup kemampuan, kesopanan dan sifat dapat di percaya yang memiliki pada karyawan bebas dari resiko, bahaya, keraguan peraguan, memiliki kompentas, percaya diri dan menimbulkan keyakinan (Obyektif)

d. Empati atau kepedulian (Emphaty) Empati meliputi kemudahan dalam melakukan hubungan komunikasi yang baik dan memahami kebutuhan konsumen yang terwujud dalam penuh perhatian terhadap setip konsumen, melayani konsumen dengan ramah dan menarik, memahami aspirasi konsumen , berkomunikasi yang baik dan benar serta bersikap dengan penuh simpati.

e. Bukti langsung atau berwujud Bukti langsung meliputi fasilitas fisik, peralatan pegawai, kebersihan (kesehatan), ruangan baik teratur rapi, berpakaian rapi dan harmonis, penampilan karyawan atau peralatannya dan komunikasi (Sriatmi et al., 2014)

\section{Kepuasan Pasien}

Menurut Kotler dan Keller yang dikutip Khairul mengatakan bahwa kepuasan merupakan tingkat keadaan perasaan seseorang setelah membandingkan kinerja suatu produk yang dirasakan dengan harapannya. Lebih jauh, kepuasan merupakan bentuk reaksi emosional terhadap pengalaman atas suatu produk atau jasa yang didasarkan oleh informasi yang digunakan untuk memiliki suatu produk.(Masitoh et al., 2019)

Kepuasan pasien adalah suatu perasaan atau keadaan pasien/keluarga yang telah mengalami suatu tindakan terhadap pelayanan yang diberikan. Pasien dikatakan puas apabila dia merasa senang, puas karena antara harapan dan kenyataan dalam memakai dan pelayanan yang diberikan terpenuhi, atau bahkan pelayanan yang diberikan melebihi harapannya indikator variabel kepuasan pasien ini yaitu : a) Keramahan petugas b) Ketepatan informasi c) Ketanggapan petugas Terpenuhinya fasilitas yang diperlukan e) Kebersihan lingkungan (Anik Tri Palupi et al., 2013)

Menurut Zeithaml yang dikutip Sriwandari bahwa kepuasan pelanggan/ pasien sangat tergantung pada persepsi dan ekspektasi pelanggan maka sebagai pemasok produk perlu mengatahui faktorfaktor yang mempengaruhinya. Ada empat faktor yang mempengaruhi persepsi dan ekspektasi pelangan yaitu: Apa yang didengar pelanggan dari pelanggan lainnya (Word Of Mounth Communication) hal ini merupakan faktor potensial yang menentukan ekspektasi pelanggan. Ekspektasi pelanggan sangat bergantung dari karakteristik individu dimana kebutuhan pribadi (Personal Needs) Pengalaman masa lalu (Past Experienence) dalam menggunakan pelayanan dapat juga mempengaruhi tingkat ekspektasi pelanggan. Komunikasi dengan pihak eksternal (External Communication) dari pemberi layanan memainkan peranan kunci dalam membentuk ekspektasi pelanggan.

\section{METODE PENELITIAN}

Jenis penelitian ini mneggnakan metode kualitatif deskriptif yang pengujian hipotesisnya menggunakan pendekatan statistik deskriptif dan statistik inteferensial. 


\section{EKOMBIS Sains}

Fokus penelitian ini bertujuan untuk menganalis tentang pengaruh kualitas pelayanan terhadap kepuasan. Objek penelitian ini adalah pasien yang dirawat inap yaitu sebanyak 48 responden di RS. Bahagia Makasar. Teknik pengumpulan data dengan menggunakan kuisioner yang diberiakan kepada pasien.

Untuk mengukur kepuasan pasien terhadap kualitas layanan kesehatan pada pasien rawat inap maka unit analisisnya adalah pasien dengan alasan bahwa :

Pertama pasien memegang posisi kunci dalam menilai pelayanan keperawatan.Alasan kedua adalah karena pasien kontak langsung dengan tenaga perawat.

Untuk mencapai tujuan penelitian dan pengujian hipotesis maka data yang diperoleh selanjutnya akan diolah sesuai dengan kebutuhan analisis. Untuk kepentingan dan pembahasan data diolah dan disajikan berdasarkan prinsip-prinsip statistik deskriptif yang menggambarkan data kualitatif dan untuk kepentingan analisis data pengujian hipotesis digunakan pendekatan statistik deskriptif dan statistik inteferensial.

\section{HASIL PENELITIAN}

Dalam peningkatan kepuasan pelanggan maka upaya yang ingin dicapai oleh setiap unit usaha adalah perlunya dilakukan analisis dimensi kualitas pelayanan. Hal ini dimaksudkan untuk melihat dimensi-dimensi manakah yang lebih dominan mempengaruhi kepuasan pasien terhadap kualitas layanan pada RS. Bahagia Makassar. Dimensi-dimensi kualitas pelayanan pengguna jasa rumah sakit dapat meliputi : tangible, reliability, responsiveness, assurance dan emphaty.

Data yang diperoleh dari responden mengenai dimensi tangible terhadap pengguna jasa layanan pada RS Bahagia dengan pernyataan bahwa bidan berpenampilan bersih dan rapi maka yang memberikan tanggapan cukup puas sebesar 9 orang atau $18,8 \%$ dan puas sebesar 39 orang atau $81,2 \%$. Dengan demikian pengguna jasa layanan merasa puas dengan bidan berpenampilan bersih dan rapi pada RS Bahagia Makassar.

Tanggapan responden atas dimensi kualitas reliability dan responsiveness, maka untuk dimensi kehandalan dengan pernyataan bahwa bidan melakukan tindakan keperawatan tepat waktu yang diberikan maka yang memberikan jawaban sangat tidak puas sebesar 11 orang $(22,9 \%)$, tidak puas sebesar 7 orang $(14,6 \%)$, kurang puas sebesar 7 orang $(14,6 \%)$, cukup puas sebesar 7 orang $(14,6 \%)$, puas sebesar 8 orang $(16,7 \%)$ dan yang memberikan jawaban sangat puas sebesar 8 orang $(16,7 \%)$, dengan demikian dapat dikatakan bahwa sebagian besar pengguna jasa layanan merasa tidak puas dan puas dengan bidan melakukan tindakan keperawatan tepat waktu yang diberikan oleh RS. Bahagia Makassar Makassar.

Tanggapan responden mengenai dimensi responsiveness, dengan pernyataan bahwa bidan mau mendengar keluh kesah pasien dengan baik yang diberikan maka yang memberikan jawaban tidak puas sebesar 1 orang $(2,1 \%)$, kurang puas sebesar 1 orang $(2,1 \%)$, cukup puas sebesar 11 orang $(22,9 \%)$, puas sebesar 21 orang $(43,8 \%)$ dan yang memberikan jawaban sangat puas sebesar 14 orang $(29,2 \%)$, dengan demikian dapat dikatakan bahwa sebagian besar pengguna jasa layanan merasa puas dengan bidan mau mendengar keluh kesah pasien dengan baik yang diberikan oleh RS. Bahagia Makassar.

Mengenai tanggapan responden atas dimensi emphaty dan assurance, maka untuk dimensi emphaty dengan pernyataan bahwa bidan senantiasa mempunyai sikap sabar dan telaten pada saat memberikan pelayanan kesehatan kepada pasien yang diberikan maka yang memberikan jawaban kurang 


\section{EKOMBIS Sains}

puas sebesar 24 orang (50\%), cukup puas sebesar 8 orang $(16,7 \%)$, dan puas sebesar 16 orang $(33,3 \%)$, dengan demikian dapat dikatakan bahwa sebagian besar pasien merasa tidak puas dan puas dengan bidan senantiasa mempunyai sikap sabar dan telaten pada saat memberikan pelayanan kesehatan kepada pasien yang diberikan oleh RS. Bahagia Makassar.

Tanggapan responden mengenai dimensi assurance, dengan pernyataan bahwa bidan memperkenalkan diri pada setiap pasien baru atau pada pergantian dinas maka yang memberikan jawaban sangat tidak puas sebesar 3 orang $(6,3 \%)$, tidak puas sebesar 9 orang $(18,8 \%)$, kurang puas sebesar 9 orang $(18,8 \%)$, cukup puas sebesar 9 orang $(18,8 \%)$, puas sebesar 9 orang $(18,8 \%)$ dan yang memberikan jawaban sangat puas sebesar 9 orang $(18,8 \%)$, dengan demikian dapat dikatakan bahwa sebagian besar pasien merasa tidak puas dan puas dengan bidan memperkenalkan diri pada setiap pasien baru atau pada pergantian dinas yang diberikan oleh RS. Bahagia Makassar.

\section{PEMBAHASAN}

Untuk menguji apakah ada pengaruh masing-masing variabel terhadap pasien, maka dilakukan uji t (uji parsial) dengan tingkat kepercayaan $95 \%$,

a. Uji hipotesis untuk variabel X1

Disimpulkan terdapat pengaruh yang signifikan antara tangible dengan tingkat kepuasan pasien disamping itu nilai probability $0,013<0,05$, menunjukkan bahwa X1 berpengaruh secara signifikan terhadap tingkat kepuasaan pasien.

b. Uji Hipotesis untukv ariabel X2

Disimpulkan tidak terdapat pengaruh yang nyata antara reliability dengan tingkat kepuasan pasien, namun hasil nilai probability $0,041<0,05$, menunjukkan bahwa X2 berpengaruh secara signifikan terhadap tingkat kepuasan pasien.

c. Uji Hipotesis untuk variabel X3

Disimpulkan terdapat pengaruh yang nyata antara responsiveness dengan tingkat kepuasan pasien, namun nilai probability $0,066>0,05$, menunjukkan bahwa X3 tidak berpengaruh secara signifikan terhadap tingkat kepuasan pasien.

d. Uji hipotesis variabel X4

Disimpulkan terdapa tpengaruh yang nyata antara emphaty dengan tingkat kepuasan pasien disamping itu nilai probability $0,013<0,05$, menunjukkan bahwa X4 berpengaruh secara signifikan terhadap tingkat kepuasaan pasien.

e. Uji hipotesis variabel X5

Disimpulkan terdapat pengaruh yang signifikan antara $\mathrm{X} 1, \mathrm{X} 2, \mathrm{X} 4, \mathrm{X} 5$ terhadap Y, hal ini menunjukkan bahwa perubahan naik turunnya dimensi kualitas pelayanan berpengaruh nyata terhadap tingkat kepuasaan pasien

\section{KESIMPULAN}

Dari hasil analisis mengenai kualitas pelayanan dan pengaruhnya terhadap kepuasan pasien pada RS. Bahagia Makassar maka dapat ditarik beberapa kesimpulan sebagai berikut :

1. Dari hasil analisis mengenai pengaruh dimensi kualitas pelayanan (tangible, reliability, assurance dan emphaty) nampak bahwa pengaruh dimensi kualitas pelayanan berpengaruh terhadap peningkatan kepuasan pasien pada RS. Bahagia Makassar.

2. Berdasarkan hasil analisis mengenai faktor-faktor yang lebih dominan dalam mempengaruhi kepuasan pasien maka dimensi kualitas pelayanan assurance yang dominan berpengaruh terhadap peningkatan kepuasan pasien karena memberikan jaminan yang memuaskan dari bidan RS. Bahagia Makassar. 


\section{EKOMBIS Sains}

\section{DAFTAR PUSTAKA}

Agustinawati. (2016). Pengaruh Kualitas Produk, Citra Merek Dan Harga Terhadap Keputusan Membeli Shampo Dove Di Kota Lhokseumawe. Jurnal Visioner \& Strategis.

Anik Tri Palupi, S., Triyaningsih, \& Sunarso. (2013). Analisis Pengaruh Kualitas Pelayanan Terhadap Kepuasan Pasien Rawat Inap Di Rs. Panti Waluyo Surakarta. Journal of Chemical Information And Modeling, 53(9), 1689-1699.

Https://Doi.Org/10.1017/Cbo97811074 15324.004

Arie Sulistyawati, N., \& Seminari, N. (2015). Pengaruh Kualitas Pelayanan Terhadap Kepuasan Pelanggan Restoran Indus Ubud Gianyar. E-Jurnal Manajemen Universitas Udayana, 4(8), 250437.

Karla, E., \& Ekonomi, F. (2015). Analisis Pengaruh Kualitas Pelayanan Terhadap Kepuasan Konsumen Pada Matahari Department Store Kramat Jati.UG Jurnal Vol 9 No. 09 9), 2-4.

Kriswandari, S. (2015). Konsumen Jasa Pendidikan Pada Stie Lampung The Factors That Influenced Consumer Satisfaction. Jurnal Managemen dan Bisnis Vol 2. No 1 Of. 1-15.

Listiyono, R. A. (2015). Studi Deskriptif Tentang Kuaitas Pelayanan Di Rumah Sakit Umum Dr. Wahidin Sudiro Husodo Kota Mojokerto Pasca Menjadi Rumah Sakit Tipe B.Jurnal Kebijakan dan Manageman Vol. 1 No.1, 1-7.

Lubis, A. S., \& Andayani, N. R. (2017_. Pengaruh Kualitas Pelayanan (Service Quality) Terhadap Kepuasan Pelanggan $\mathrm{Pt}$. Sucofindo.Jurnal of Busines Administration 1(2).
Marthalena, Y., \& Nuryanto, M. (2017). Hubungan Kualitas Pelayanan Keperawatan Di Rumah Sakit Umum Kartini Kecamatan Kalirejo Kabupaten Lampung Tengah Tahun 2015. Ekombis Sains Jurnal Ekonomi Keuanga Dan Bisnis Universitas Sang Bumi Ruwa Jurai, 02(02), 151-168.

Masitoh, M. R., Wibowo, H. A., \& Ikhsan, K. (2019). Pengaruh Kualitas Pelayanan , Kepuasan Pelanggan , Dan Kepercayaan Merek Terhadap Loyalitas Pelanggan Pada Pengguna Aplikasi Mobile Shopee. Jurnal Sains Manajemen, 5(1), 101-119.

Permana, A. (2016). Pengertian Rumah Sakit. Repository.Unisba.Ac.Id, 17-50.

Radito, T. (2014). Analisis Pengaruh Kualitas Pelayanan Dan Fasilitas Kesehatan Terhadap Kepuasan Pasien Puskesmas. Jurnal Ilmu Manajemen, 11(2), $1-25$. Https://Doi.Org/10.21831/Jim.V11i2.1 1753

Sriatmi, A., Suryawati, C., \& Hidayati, A. (2014). Analisis Hubungan Karakteristik Pasien Dengan Kepuasan Pelayanan Rawat Jalan Semarang Eye Center (Sec) Rumah Sakit Islam Sultan Agung Semarang. Jurnal Kesehatan Masyarakat (E-Journal).

Ulumiyah, N. H. (2018). Meningkatkan Mutu Pelayanan Kesehatan Puskesmas Improving T He Health Services' Quality By Implementation Of Patient Safety In Public Health Center. 6(2), 149-155.

Https://Doi.Org/10.20473/Jaki.V6i2.20 18.149-155

Wanrajib Azhari Manurung. (2015). Perancangan Rumah Sakit Umum Daerah (Rsud) Kelas C Non-Pendidikan Berbasis Low Cost Di Kota 


\section{EKOMBIS Sains}

Tanjungbalai Tema : Low Energy. Rsud Berbasis Low Cost, Sistem Pada Rumah

Sakit. 10-129. 